\title{
THE INFLUENCE OF SOCIAL INTERNET NETWORKS ON THE SOCIALIZATION OF YOUNG PEOPLE
}

УДК 316.4.06:004.77

DOI https://doi.org/10.32843/26635208.2021.29.7

\section{Буковська 0.0.}

к.психол.н.,

доцент кафредри психології

Чернігівський обласний інститут післядипломної педагогічної освіти імені К.Д. Ушинського

\section{Мазур T.B.}

к.психол.н.,

доцент кафредри психології

Чернігівський обласний інститут післядипломної педагогічної освіти імені К.Д. Ушинського

\section{Анищенко Л.о.}

старший викладач кафредри психології Чернігівський обласний інститут післядипломної педагогічної освіти імені К.Д. Ушинського
Стаття присвячена аналізу соціалізації молоді в умовах інфрорматизації суспільства. Підкреслюється, що у сучасному інфоормаційному суспільстві конструюється новий тип соціального індивіда - Hoто virtualis, людини як споживача і носія віртуальної культури.

Проаналізовані теоретичні підходи до проблем соціалізації в умовах віртуального інфрормаційного середовища, зміни світогляду до соормування віртуальної особистості. Визначено вміст поняття «інтернет-соціалізація», «віртуальна особистість».

Показано, що соціальні мережі як інститут соціалізації молоді фрормують нові моделі поведінки, установки, норми та цінності, виступаючи особливим соціальним простором, де трансорормуються традиційні фоорми соціалізації.

Висвітлюються результати емпіричного дослідження впливу соціальних інтернетмереж на соціалізацію молоді.

Виявлено, що провідними мотивами перебування студентської молоді у соціальних мережах $є$ задоволення потреби у комунікації, самовираженні та прояві свободи особистості, що пов'язано з можливістю вільно висловлювати думку, проявляти i підтримувати бажану віртуальну індивідуальність. Поряд із цим соціальні мережі задовольняють і мотив афріліації, який відображає потребу молоді бути включеною у соціальну спільноту, де поділяються їі погляди. Таким чином, соціальні мережі як інститут соціалізації дозволяють випробовувати бажані соціальні ролі та вибудовувати різні ідентичності. Доведено, що соціальні мережі чинять соціалізаційний вплив на сучасну молодь поряд із іншими інститутами соціалізації (сім'єю та друзями). Співвідношення між цими інститутами може бути збалансованим, $і$ тоді соціальні мережі сприяють формууванню нових форм взаємодії суб'єкта і середовища. Натомість домінування соціальних мереж над іншими традиційними інститутами соціалізації може призвести до відхилень у фрормуванні особистісних якостей молоді, формуючи різні види девіацій.

Ключові слова: інфрормаційне суспільство, соціальний досвід, соціалізація молоді, кіберсоціалізація, інтернет-комунікація, мотивація звернення до соціальних мереж, соціальні мережі.

The article is devoted to the analysis of socialization of youth under the conditions of informatization of society. It is emphasized that in the modern information society a new type of social individual is being formed - Homo virtualis - a person as a consumer and bearer of virtual culture.

The theoretical approaches to solving the problem of socialization in a virtual information environment; defined the concept of "online socialization", "virtual identity"; developed a model of online socialization; defined results online socialization that are in the continuum of change in attitudes to the formation of a virtual personality.

It is shown that social networks as an institution of youth socialization form new models of behavior, attitudes, norms and values, acting as a special social space where traditional forms of socialization are transformed.

The results of an empirical study on the impact of social networks on the youth socialization are presented.

It has been found that the leading motives of student youth to use social networks are to meet the need for communication, self-expression and expression of individual freedom, which is associated with the ability to freely express opinions, show and maintain the desired virtual individuality. In addition, social networks satisfy the motive of affiliation, which reflects the need of young people to be included in the social community, where their views are shared. Thus, social networks as an institution of socialization allow us to experience the desired social roles and, consequently, form different identities.

It has been proven that social networks have a socializing impact on modern youth, along with other institutions of socialization (family and friends). The relationship between these institutions can be balanced, and then social networks contribute to new forms of interaction between the subject and the environment. Instead, the dominance of social networks over other traditional institutions of socialization can lead to deviations in the formation of personal qualities of young people.

Key words: information society, youth socialization, social experience, cyber-socialization, Internet communication, motivation to turn to social networks, social networks.
Вступ. Сучасні соціальні транссрормації відбуваються в умовах переходу від індустріального суспільства до інсрормаційного, що сприяє усвідомленню пріоритетності інсрормації перед іншими продуктами діяльності людини.

Особливе значення інформації, її визначальна роль у фрункціонуванні суспільства сформувала й особливий світогляд нової епохи, головною рисою якого $є$ плюралізм. Склалася унікальна ситуація, коли перед людиною відкрилася нескінченна можливість вибору власної ідентичності. Ця ситуація має подвійний характер. 3 одного боку, людина зіштов- хується із проблемою вироблення орієнтирів у гетерогенному світі в умовах нескінченного потоку нової інфрормації, що ускладнює вироблення ціннісних орієнтирів, з іншого - така ситуація забезпечує максимальне втілення свободи, дає поштовх до безмежного самовираження і творчості.

Також для інфрормаційного суспільства характерна високий ступінь комунікації через соціальні мережі, що стало для багатьох (особливо молоді) своєрідним способом життя. Варто зазначити, що спектр реалізованих за рахунок веб-платорорм суспільних відносин перебуває у постійній динаміці. 
Якщо раніше соціальна мережа була лише технологічним засобом комунікації, то зараз вона є масштабним комунікативним простором, у структурах якого стає можливим навіть ведення повноцінної освітньої діяльності.

Таким чином, посилення інфрормаційної компоненти створює новий життєвий простір людини в інтернет-мережі та супроводжується змінами, які в умовах трансорормування традиційних агентів соціалізації фрормують нові установки, норми та цінності особистості. Тому особливий інтерес у цьому контексті становлять питання соціалізації молоді.

Виклад основного матеріалу дослідження. Фахівці з комунікацій, психологи, соціологи відзначають зростання впливу сучасних інорормаційно-комунікаційних технологій на соціалізацію молоді. Молоді люди починають переносити способи діяльності, фрорми поведінки 3 віртуального простору у повсякденне життя. З'явилося навіть поняття «Homo virtualis» - людини, орієнтованої на віртуальність, споживача віртуальної культури.

За результатами опитування, проведеного дослідницькою компанією Factum Group на замовлення інтернет-асоціації України, станом на 2020 рік частка користувачів інтернету становить $71 \%$ (22,96 млн), 65\% населення мають інтернет вдома. Найактивнішими в інтернеті $є$ молодь. Так, частка користувачів віком від 15 до 24 років становить 97\%, від 25 до 34 років - 96\%. Майже кожна третя особа, старша 65 років, $€$ користувачем інтернету (рік тому було лише 14\%) [3].

Незважаючи на те, що вивчення впливу віртуального простору на соціокультурний простір сучасного суспільства розпочалося ще в останні десятиліття минулого століття, дотепер серед дослідників відсутня єдність думок як із приводу ступеня такого впливу, так і щодо його спрямованості. Включення категорії інфрормаційного суспільства як чинника й умови соціалізації - новий аспект досліджень цієї проблеми.

Сьогодні у вітчизняній науці тема соціалізації в освітньому або загальнокультурному аспекті викликає дедалі більшу увагу дослідників і розглядається у різних ракурсах.

Розгляд проблеми соціалізації лежить у міждисциплінарному просторі, який інтегрує дискурс поліпарадигмальності. Проблеми соціалізації розробляли зарубіжні (Л. Колберг, А. Оллпорт, А. Маслоу, К. Роджерс, Дж. Мід), а також українські науковці В.М. Бондаровська [1], О.М. Немеш [7], І.І. Киричок [7], М.П. Лукашевич [5], О.В.Петрунько [8], О.О. Буковська [2], Т.В. Мазур [6] та ін.

Насамперед необхідно виділити теорію кіберсоціалізації російського дослідника В.А. Плешакова [9] котрий запропонував поняття «кіберсоціалізація», презентуючи його як процес якісних особистісних і мотиваційних змін індивіда під впливом використання віртуальних засобів і комунікаційних технологій наявної культури, її засвоєння і відтворення. Результатом кіберсоціалізації, на думку автора, $є$ створення «кібер-альтер-его», яке передбачає створення віртуального образу себе, актуального для сучасної життєдіяльності не тільки у віртуальному, а й у реальному просторі.
Досліджуючи вплив віртуального простору на соціалізацію молоді, ми виходимо з основних концептуальних положень соціалізації Т. Парсонса та Р. Мертона, згідно з якими соціалізація є пристосування людини до культурних та інших фракторів середовища. А. Маслоу, К. Роджерс розглядали соціалізацію як процес подолання негативних впливів середовища, впровадження власних можливостей і здібностей. щоб успішно влитися у суспільство, реалізуватися, підростаюче покоління опановує соціальний досвід, засвоює культурні цінності, зразки поведінки, прийняті у суспільстві, і тим самим самоактуалізується і самореалізується.

Відзначимо, що у вивчених позиціях відстоюється думка про те, що процес інтернет-соціалізації не тільки виступає сучасним механізмом і транслятором інституційних норм, правил, практик сучасного соціуму і культури, а й розширює межі, зближуючи суб'єктів із протилежними паттернами та зразками мислення, розширюючи межі звичної соціально-культурної ситуації та поглиблюючи комунікативні компетенції.

Узагальнюючи публікації, де досліджуються процеси соціалізації особистості у контексті віртуального простору, можна виділити два ракурси цієї проблеми: перший стосується ступеня освоєння суб'єктом самого кіберпростору, другий виділяє віртуальну соціалізацію як умову реальної фрактичної соціально-значущої соціалізації.

Метою статті $€$ опис результатів дослідження впливу соціальних інтернет-мереж на соціалізацію молоді та специсріки прояву соціальних цінностей у ставленні молоді до провідних інститутів соціалізації.

Дослідження впливу соціальних інтернет-мереж на соціалізацію молоді здійснювалося методом фрокус-групи, у якому взяли участь 12 студентів: 6 юнаків і 6 дівчат віком від 19 до 22 років. Учасникам фокус-групи пропонувалося обговорити мотиви, мету, причини, частоту перебування у соціальних інтернет-мережах. Доповненням до результатів фрокус-групи стало анкетне опитування.

Особливості прояву соціальних цінностей у ставленні молоді до провідних інститутів соціалізації вивчалося методом семантичного диференціалу. у дослідженні взяли участь 125 студентів 3-4 курсів Національного університету «Чернігівський колегіум» імені Т.Г. Шевченка.

Підтвердженням того, що саме соціальні інтернет-мережі є однією з головних цілей їх використання, $€$ висловлювання учасників фрокус-групи. «Для мене інтернет - це насамперед можливість користуватися соціальними мережами», «Так, справді, у мене й у моїх друзів у розмовах про інтернет відразу говоримо про Facebook, Instagram, Twitter», «Через соціальні мережі можна все зробити в цьому світі: купити одяг і їжу, подивитися фрільм, почитати книгу, поговорити 3 друзями, попрацювати, врешті-решт».

Дійсно, з огляду на висловлювання учасників фокус-групи можна з упевненістю сказати, що поряд зі світом реальним склався особливий світ кіберпростору, або е-культура, яка якісно трансорормує модель реальності. Донедавна ці процеси відбувалися у прихованій фрормі, але бурхливий розвиток і поширення комп'ютерних технологій і глобальних 
інформаційних мереж кардинальним чином змінили соціум, зробивши інорормаційні засоби та технології своєрідними інсормаційними органами, «продовженнями» людини [5].

Необхідність організації життєдіяльності людини в інтернет-просторі щодня стає реальнішою й актуальнішою. Практично для кожної сучасної людини стало нормою бути зареєстрованим і користуватися хоча б однією із соціальних інтернет-мереж, вести свій блог і бути завжди у режимі онлайн.

Про це свідчать і дані, отримані у фрокус-групі. Усі учасники дослідження вказали, що вони зареєстровані не менше, ніж у втрьох соціальних інтернет-мережах, у жодного учасника фрокус-групи не знайшлося знайомого, який би не був зареєстрований хоча б в одній із соціальних мереж.

Як з'ясувалося, молоді люди у 95\% випадків постійно знаходяться на онлайн-зв'язку: «відразу відповідаю на повідомлення», «постійно у курсі всіх новин своїх друзів», «у середньому кожні півгодини або годину переглядаю стрічку», «цікавлюся фото різних людей, хто, де був і у кого, що сталося в житті».

Для молодих людей соціальні інтернет-мережі перетворилися на зручний засіб задоволення будьяких потреб. «Ну, от уявіть собі, зима, людина сидить вдома, їй зручніше буде поговорити зі своїм другом в інтернеті, ніж вийти на вулицю для того, щоб зустрітися 3 кимось. Для цього потрібно одягатися, фрарбуватися, робити зачіску, зараз це абсолютно ні до чого».

Однак молоді люди все ж усвідомлюють, що «одночасно це дуже затягує, тому що ти не помічаєш, як плине час. Начебто ти розумієш, що тобі потрібно виконати якісь завдання, але думаєш, що ось я зараз на хвилиночку зайду в інтернет, оновлю стрічку і все, а в підсумку, коли прийшов до тями, то вже три години пройшло, а ти так нічого і не зробив».

Молоді люди переважно відзначають, що соціальні інтернет-мережі $€$ позитивним явищем сучасного життя. «Соціальні мережі?! Так, це дуже зручно! Тому, що в одному місці зібрані і фрільми, і музика, й ігри. Можна подивитися фротографрії знайомих, висвітлити якось своє життя, висловити свою думку». «Раніше, щоб обговорити якісь речі, люди виходили на вулицю, удвох, якщо це щось особисте, або компанією, то зараз в інтернеті можна спілкуватися одночасно з усіма: і зі своїм хлопцем, і з подругою, ти встигаєш відповідати всім і зі всіма все обговорювати!». «Так само ще групи, наприклад, в "ВКонтакте" можна знайти будь-які теми: починаючи від психології і закінчуючи улюбленими серіалами, тобто можна бути в курсі всіх подій», «так само ще 3 допомогою інтернету можна заощадити гроші, тобто замість того, щоб сходити в кіно, можна подивитися фрільм вдома з інтернету», «спілкуватися на великих відстаняХ».

На думку молодих людей, ще однією перевагою соціальних інтернет-мереж $є$ той оракт, що «соціальні мережі допомагають вирішувати проблеми». «Проблему самотності, тобто людина заходить у мережі, починає спілкуватися, бачить, що інші люди сидять там, і їй здається, що вона не одна, що з нею хтось спілкується». «Немає проблеми сором'язливості, тобто ти можеш створити свою сторінку, якщо хочеш показати себе людям із того боку, з якою ти хочеш, щоб тебе бачили люди». «Ще через анонімні сайти ти можеш спілкуватися, не показуючи себе». «Також є така проблема, що деякі люди бояться йти до реальних психологів, вони бояться цього реального спілкування і соціальні мережі замінять їм це. $€$ ж різні онлайн-психологи, або ж можна зареєструватися під іншим ім'ям і фотографрією, так, що тебе не впізнають, і тим самим ти можеш розкритися повністю і бути впевненим у тому, що тебе не впізнають, не впізнають твого обличчя і твого імені».

«Можна замовляти продукти додому, тобто люди, які не можуть піти за продуктами, або бабуся стара, тобто суть у тому, що внучка бабусі може замовити їжу додому й оплатити 3 картки, і їй привезуть ці продукти додому. I так само звичайні люди, якщо їм не хочеться, або терміново щось треба, теж можуть замовити продукти і їм привезуть їх. Це зручно!». «Люди 3 обмеженими можливостями - вони не можуть знайти роботу в нашому звичайному світі, і інтернет та різні мережі допомагають спілкуватися, заробляти гроші, заробляти собі на життя».

У зв'язку з висловленими думками учасників фокус-групи цікаво відзначити суперечливі судження у дослідженнях сучасних вчених із приводу виникнення нових моделей соціальної взаємодії. 3 одного боку, соціальні інтернет-мережі, що базуються на онлайновій комунікації, описуються як кульмінація історичного процесу поділу місця життя і соціальності: нові моделі соціальних відносин приходять на зміну фрорм взаємодії між людьми, заснованих на територіальних зв'язках. 3 іншого боку, думки і дослідження вчених зводяться до того, що поширення інтернету сприяє соціальній ізоляції, розриву громадських зв'язків і руйнуванню сімейного життя, відмові від особистої взаємодії у реальних умовах. Інтернету ставиться у провину те, що він поступово «заманює» людей спокусою жити фантазіями у режимі онлайн, в умовах культури, у якій домінує віртуальна реальність [8]. Тому для сучасної людини, присутньої у двох протилежних один одному просторах: предметному світі та світі символьно-знакового кіберпростору [5], проблема самовизначення постає у новому ракурсі. Предметний світ як сукупність різних соціальних інститутів чітко структурує життя людини й обмежує її поведінку. Світ кіберпростору безмежний і накладає на людину менше обмежень у процесі їі самоідентифікації.

у зв'язку з цим у міру розвитку технологій віртуальної реальності та впровадження їх у повсякденне життя у людини виникає необхідність бути представленою у кіберпросторі, оскільки фракт знаходження людини у мережі $є$ однією з умов сучасної соціалізації [4].

Отже, найбільш суттєві відмінності, які виникають у ході інтернет-соціалізації, пов'язані з часом перебування у мережі, частотою перебування й інтенсивністю і насиченістю віртуальної міжособистісної взаємодії. Соціальні мережі для певної частини молоді витісняють реальне коло знайомств, їм стає простіше спілкуватися 3 невидимим співрозмовником, створюючи свій новий образ «Я».

у рамках традиційних соціальних інститутів соціалізація здійснювалася у процесі комунікації 
особистості з оточенням: батьками, вчителями, друзями. Кількість персонісікованих агентів соціалізації було відносно невеликою через обмеження у можливості контактувати із представниками соціуму. Принципово іншою $є$ інтернет-комунікація. Тут у режимі реального часу особистість може вступати у практично необмежену кількість комунікацій за рахунок використання таких технологій, як чати, блоги тощо.

Вплив сучасних інститутів соціалізації на особистість вивчався методом семантичного диференціалу в адаптації В. Петренка.

Респондентам було запропоновано визначити вплив інститутів соціалізації (сім'ї, освітніх установ, друзів, ЗМІ та соціальних мереж) за базовими смисловими шкалами, включаючи такі пункти, як сила впливу, оцінка (привабливість) та активність. Провівши статистичний аналіз розподілу відповідей за критерієм $\chi 2$, ми виявили суттєві відмінності впливу запропонованих для аналізу інститутів соціалізації за критеріями активності й оцінки. Так, за критерієм оцінки (привабливості) соціальні мережі зайняли перше місце, після якого розташувались «сім'я» і «друзі. Студенти відзначали інтернет-простір як позитивний, той, що сприяє розслабленню, відпочинку.

За критерієм активності було визначено, що інтернет-простір спонукає до активних дій. Ці результати вказують на важливість інтернету як простору для індивідуальної соціалізації.

Для подальшого аналізу онлайн-соціалізації ми розглянули мотиваційну складову частину цього процесу.

Дослідження мотиваційного компоненту інтернет-соціалізації виявило, що не лише конкретні обставини інтернет-простору, але й деяке незадоволення потребами людини у реальному житті призводять до появи нових мотивів.

Переважна більшість опитаних студентів (93,2\%) провідним мотивом використання соціальних мереж назвали комунікативний, що узгоджується 3 даними фокус групи. Пізнавальна складова частина мотивації проявляється вдвічі менше: 48,8\% студентської молоді керуються мотивом швидкого пошуку потрібної інформації та життєвою цікавістю («бути у курсі подій із життя друзів»).

Третє місце посів мотив афріліації, який відображає одну із ключових потреб молоді - бути включеними у соціальну спільноту, де поділяються ії погляди (цей варіант обрали 43\%).

Мотив свободи у соціальних мережах виявився вирішальним для 84\% досліджуваних. Свобода пов'язана з пошуком ідентичності, можливістю створювати бажаний образ і підтримувати його. Тут, 3 одного боку, проявляється примірювання різних образів і випробовування їх у соціальних мережах, а 3 іншого - потреба у самовираженні, можливості вільно висловлювати думку, проявити індивідуальність.

Таким чином, соціальні мережі є одним із найбільш відкритих і насичених можливостями самовираження просторів в інтернеті.

Висновки 3 проведеного дослідження. Результати дослідження засвідчили, що інтернет-соціалізація студентської молоді пов'язана 3 часом перебування у мережі, частотою перебування, інтен- сивністю та насиченістю віртуальної міжособистісної взаємодії. Соціальні мережі для певної частини молоді витісняють реальне коло знайомств, їй стає простіше спілкуватися 3 невидимим співрозмовником, створюючи свій новий образ «Я».

Таким чином, соціальна мережа стає новим інститутом соціалізації сучасної молоді, який задовольняє їх соціальні потреби, надає високий ступінь свободи та самореалізації, дозволяє подолати комунікативний бар'єр, десріцит спілкування. Водночас широкі комунікативні можливості соціальних мереж породжують нові норми, цілі, цінності, правила, прийняті не у реальному суспільстві, у якому живе молодь, а в тому чи іншому мережевому співтоваристві, де домінують норми та цінності, що не мають міцних історико-культурних коренів, не пов'язані з буттям соціуму, з його цінностями. Розбіжність мережевих норм і цінностей із ціннісними нормами суспільства може привести до конорлікту між особистістю, котра засвоїла «мережеву культуру», із тим суспільством, у якому вона живе.

Молоді люди, занурені у віртуальне інформаційно-комунікативне середовище, не тільки зводять до мінімуму реальне спілкування із представниками інших вікових категорій, а й практично відмовляються від спілкування «в офрлайні» зі своїми однолітками, втрачаючи здатність проявляти справжні почуття, висловлюючи їх виключно віртуально. Опитування показало, що спілкування в інтернет-просторі негативно впливає на процес соціалізації молоді через заміну взаємодії міжособистісного характеру, необхідної для соціалізації, соціальною мережею.

Вивчення соціалізаційного впливу на особистість з боку інтернет-середовища у співвідношенні із впливами інших інститутів соціалізації показало, що вони можуть бути як збалансованими та сприяти формуванню нових форм взаємодії суб'єктів у середовищі інтернету, так і відсутніми або домінуючими, що може призвести до відхилень у соціалізаційному процесі особистості.

\section{ЛITЕРАТУРА:}

1. Бондаровська В.М., Пов'якель Н.І. У мережі Інтернет: психологічні, етичні, культурологічні проблеми. Психолог. 2005. № 25 (169). С. 10-15.

2. Буковська О.О. Просоціальна спрямованість та поведінка особистості. Актуальні проблеми психології: Збірник наукових праць Інституту психології імені Г.С. Костюка. Екологічна психологія. 2019. T. VII. Вип. 47. С. 120-129.

3. Дані досліджень інтернет-аудиторії України за грудень 2019. Інтернет Асоціація України URL: http://https://inau.ua/news/dani-doslidzhen-internetaudytoriyi-ukrayiny-za-gruden-2019 (дата звернення: 13.04.2021)

4. Киричок І.І. Вплив Інтернету на морально-духовні та соціальні цінності старшокласників. Психолого-педагогічні науки. 2015. № 3. С. 108-113.

5. Лукашевич М.П. Особливості соціалізації української молоді в сучасних умовах. Теорія і практика управління соціальними системами: фрілософрія, психологія, педагогіка, соціологія. 2009. № 4. С. 34-36. 


\section{ГАБІТУС}

6. Мазур Т.В. Соціально-психологічні аспекти самореалізації особистості в сучасних умовах. Проблеми соціальної роботи: фрілософрія, психологія. 2013. № 1. C. 117-121.

7. Немеш О.М. Віртуальна діяльність особистості: структура та динаміка психологічного змісту : монографрія. Київ : Слово, 2017. 391 с.
8. Петрунько О.В. Інтернет як технологія соціалізації дітей та молоді. Педагогіка і психологія. 2010. № 1. С. 85-95.

9. Плешаков В.A. Киберсоциализация человека: от Homo Sapiens'a до Homo Cyberus'a : монографиия. Москва : МПГУ, «Прометей», 2012. 212 c. 